\author{
B.C. Копча
}

\title{
СЕПСИС - СИНДРОМ ЧИ ІНФЕКЦІЙНА ХВОРОБА? ЕВОЛЮЦІЯ ДИЛЕМИ
}

Тернопільський державний медичний університет ім. І.Я. Горбачевського

Мета роботи - звернути увагу лікарів на невідповідності «нових» уявлень про сепсис, нав'язаних лікарському співтовариству і безумовно прийнятих не лише анестезіологами-реаніматологами та хірургами, але й багатьма інфрекціоністами.

Визначаючи наріжним каменем при сепсисі «системність» запальної відповіді у вигляді цитокінових порушень, автори відповідної концепції змушені визнавати етіологічними фракторами практично усіх без винятку збудників інфекційних захворювань (від вірусів до найпростіших), які закономірно перебігають з підвищенням активності цитокінів у сироватці крові. Не применшуючи значення цих важливих компонентів запалення, варто звернути увагу на постулат про те, що не тільки віруси та найпростіші ніколи не спричиняють сепсис, але й усі «небактеріємічні збудники» (клостридії ботулізму та правця, бордетелли кашлюка, дифртерійні палички, холерні вібріони та ін.) за визначенням не бувають етіологічними оракторами цього захворювання, хоча й неодмінно зумовлюють тяжкі системні реакції, що супроводжуються збільшенням рівня прозапальних цитокінів.

Тому сепсис - це генералізована ациклічна інфрекційна хвороба бактерійної та/або грибкової етіології, що розвивається в імунодефіцитному організмі з характерними патоморфологічними і патогістологічними змінами в органах і тканинах.

Наведено детальний аналіз клінічного випадку сепсису у молодої жінки, яка завдяки адекватній активній хірургічній та потужній і тривалій консервативній терапії благополучно одужала.

Ключові слова: сепсис; синдром системної запальної відповіді; діагностика; лікування.

Не так важливе знання як розуміння, тобто не лише обізнаність, але й проникнення у суть.

Р. Декарт

Взятися за написання цієї статті спонукали дві обставини. Перша - редакторська діяльність. Беручи участь у редагуванні роботи одного науковця, натрапив на беззастережне тлумачення ним сепсису як «синдрому системної запальної відповіді - CC3B або SIRS». Друга - клінічний випадок, який в силу обставин майже збігся у часі з опрацюванням згаданої теми.

Сепсис - украй тяжке і небезпечне інсекційне захворювання. Тому він виділений в окрему самостійну нозологічну фрорму задовго до відкриття його збудників. Сепсис відомий медицині з античних часів, що становить більше 2 тисячоліть. Проте медичні задачі, що визначають ситуацію із сепсисом, не вирішені. У той же час, сучасні зміни інфектологічних обставин висувають нові вимоги.

Лікування сепсису, як і всякого захворювання, ґрунтується на відомостях про його патогенез. Проте найзначніші труднощі виникають саме при визначенні й викладі суті патогенезу сепсису. Вказані труднощі пов'язані з тим, що із сепсисом стикаються лікарі практично усіх клінічних спеціальностей, а також анестезіологи/реаніматологи - фахівці синдромального профрілю.

Як відомо, у 1991 р. в Чикаго на погоджувальній конфреренції Американської асоціації товариства критичної медицини і торакальних хірургів було ухвалене визначення сепсису як синдрому системно-запальної відповіді (CC3B, SIRS), безпосередньою причиною розвитку якого визначена гіперпродукція прозапальних цитокінів - фрактора некрозу пухлин-альфа (TNF- $\alpha$ ), інтерлейкіну-1 (IL-1), інтерлейкіну-6 (IL-6) та інших, зміни вмісту яких в організмі отримали на папері ефектні характеристики: «медіаторний каскад», «цитокінова буря», «цитокінова пожежа» тощо [1-3].

Але саме після цього (чи внаслідок цього?!), сепсис і став найбільш летальним з усіх бактерійних інфекцій. Від нього стало помирати більше хворих, ніж від усіх бактерійних інфекцій разом узятих. Згодом помилковість таких уявлень продемонстрували більше 30 проспективних рандомізованих досліджень, що показали не лише неефективність, але й небезпеку дорогої антицитокінової протизапальної терапії [4-8]. 
Таким чином, синдромальне уявлення про патогенез сепсису не відповідає природі цього захворювання. Відтак лікування таких пацієнтів, що базується на синдромальній патогенетичній основі, залишається неефективним і від сепсису продовжують помирати до 50 \% хворих [4-9].

Оскільки відомо, що «на початку було слово», то всяка реорганізація повинна починатися з роз'яснень і уточнень.

Інфекційні захворювання характеризуються чіткою клінічною своєрідністю і різноманіттям через те, що збудники кожної 3 інфееційних недуг містять специфрічний набір різноманітних антигенів, а кожна з інфекцій відрізняється своїми особливостями розвитку патологічного процесу. Проте на тлі особливої різноманітності кожного з інфекційних захворювань сепсис вирізняється ще більшою «оригінальністю» тому, що його розвиток зумовлений подвійною своєрідністю - антигенною і патогенетичною. Вказані особливості вимагають об'єктивного з'ясування.

Мета роботи - звернути увагу лікарів на невідповідності «нових» уявлень про сепсис, нав'язаних лікарському співтовариству і безумовно прийнятих не лише анестезіологами-реаніматологами та хірургами, але й багатьма інфекціоністами.

Сепсис суттєво відрізняється від усіх інших інсрекційних захворювань. При ньому не буває стертих і легких форм. Такі хворі не контагіозні тому, що для розвитку зазначеної недуги потрібне не лише інфрікування та фрормування інорекційного процесу, але одночасно й виснаження протективних і репаративних ресурсів імунітету пацієнта.

Одномоментне поєднання усіх вказаних патогенетичних обставин настільки малоймовірне, що зараження сепсисом безпосередньо від хворого до здорового практично не реалізується.

Сепсис - поліетіологічна інфекція, збудниками якої можуть бути бактерії і гриби, здатні зумовлювати бактеріємію і фрунгемію. «Небактеріємічні збудники» дифртерії, холери, правця, ботулізму, кашлюка і подібні до них ніколи не спричиняють сепсис. Натомість збудниками сепсису $є$ переважно маловірулентні та умовно-патогенні бактерії і гриби - постійні мешканці відкритих і напіввідкритих порожнин людського організму. Чому споконвічне співіснування 3 ними, ймовірно необхідне з позицій імунітету, в окремих випадках виливається у сепсис, залишається остаточно нез'ясованим [4-6]. Високовірулентні мікроорганізми не фрігурують як збудники сепсису, як тому, що контакт з ними різко обмежений цілеспрямованими зусиллями протиепідемічної служби, так і тому, що захворювання, зумовлені високовірулентним збудником, наприклад, S. typhi, хоча й може розви- нутися в клінічній фрормі сепсису, реєструється тільки як «черевний тифр», але не сепсис.

Таким чином сепсис - генералізоване ациклічне інфекційне захворювання бактерійної та/або грибкової етіології, що розвивається в імунодефріцитному організмі 3 характерними патоморфологічними і патогістологічними змінами в органах і тканинах [4-6]. Представлене нозологічне визначення з етіологічним уточненням може вважатися достатнім, тому що дозволяє зрозуміти природу хвороби, пояснити причину появи і розвитку характерних для сепсису симптомів і особливостей його клінічного перебігу, а також підводить необхідну теоретичну базу під діагностику і успішну терапію.

Віруси та найпростіші не виявлені як збудники сепсису шляхом клінічних і патоморфологічних досліджень $[10,11]$.

Захворювання сепсисом, як і будь-якою іншою інфекційною хворобою, розпочинається 3 формування вогнища інфекції. Первинне вогнище при сепсисі з моменту його утворення формується як сепсисне («септичне») вогнище, тобто місце проліферації і дисемінації збудника/збудників, які інтенсивно пригнічують фрункції імунітету хворих. На відміну від інфекційного, сепсисне вогнище залишається не лише місцем репродукції збудника/збудників, але і стає джерелом їх дисемінації 3 формуванням нових, вторинних, додаткових сепсисних вогнищ і посиленням негативного тиску антигенів збудників сепсису на фрункції імунітету.

Стан імунітету є, як відомо, фрактором, що зумовлює розвиток сепсису. Генералізована інфекція може перебігати як завгодно тяжко, але, поки розмноження збудника/збудників в інорекційному вогнищі/вогнищах контролюється імунітетом, розвиток недуги відбувається циклічно і закінчується одужанням, якщо не стається небезпечних ускладнень, що порушують доброякісну циклічність.

3 моменту утворення сепсисного запального вогнища хвороба неминуче прогресуватиме, якщо сепсисний самопідтримуваний процес не буде перерваний терапевтичним втручанням. Репродукція збудника/збудників у сепсисних вогнищах контролюється імунітетом не належним чином або зовсім не контролюється, через що інорекційне вогнище стає сепсисним, а захворювання розвивається ациклічно, тобто як сепсис. Первинно сорормоване сепсисне вогнище на початковому етапі підтримує постійну, але не обов'язково інтенсивну бактеріємію/срунгемію, тому стан хворих на цій стадії хвороби може залишатися середньотяжким, а самопочуття - відносно задовільним.

Період хвороби, коли в організмі $є$ тільки первинно сорормоване сепсисне вогнище і пов'язана з ним сепсисна бактеріємія (фунгемія), отримав назву початкової 
септицемії. Септицемічний період $€$ початковим. Тому він може перебігати при ще відносно задовільному самопочутті. Якщо буде призначене адекватне лікування в період початкової септицемії, вислід виявиться найкращим. Для повного лікування буде потрібно тільки пригнічення і/або ліквідація збудника/збудників як першопричини недуги.

Тривалість періоду септицемії - від декількох діб до декількох тижнів, становлячи в середньому близько 7-10 діб. Без спеціального лікування септицемія не може закінчитися одужанням, тоді як несепсисна бактеріємія, якщо не відбувається небезпечних ускладнень, зберігає можливість спонтанного одужання.

Внаслідок інтенсивного розмноження збудника/ збудників у сепсисному вогнищі/вогнищах організм хворого переповнюється інсрекційними агентами та їх токсинами з розвитком характерної інтенсивної сепсисної бактеріємії і сепсисної інтоксикації. Антигени і суперантигени збудника/збудників сепсису пригнічують протективну і репаративну функції імунітету, через що сепсис розвивається з безперервною послідовністю, тобто тільки «по наростаючій». Тому спонтанне одужання при цій хворобі недосяжне [5].

Усі особливості сепсисного процесу: септицемія (інтенсивна бактеріємія 3 дисемінацією збудника/збудників і утворенням вторинних сепсисних вогнищ), відсутність легких і стертих фрорм хвороби, наростаюча тяжкість і неможливість спонтанного одужання - ациклічність, що довго були і продовжують бути предметом непорозумінь і суперечок, логічно й обґрунтовано пояснюються сепсисною імунною недостатністю [6].

Оскільки сепсисний процес неухильно прогресує, то стадія септицемії (сепсисної бактеріємії), закономірно змінюється стадією септикопіємії - завершальною стадією сепсису, коли формуються сепсисні гнійно-запальні вогнища. Слід підкреслити, що, хоча початкова септицемія може і не супроводжуватися вираженою інтоксикацією, можливі особливо тяжкі клінічні варіанти сепсису, коли небезпечна інтоксикація розвивається 3 першої години хвороби. Сюди належать синус-тромбоз сепсис, отогенний сепсис, особливо тяжкий гінекологічний сепсис, найгостріший сепсис з первинним інфрекційно-токсичним (сепсисним) шоком.

У стадії септицемії, тобто при сфрормованому первинному сепсисному вогнищі і в початковому періоді формування вторинних сепсисних вогнищ, стан хворих, як вже вказувалося, може залишатися не обов'язково тяжким, тому що $з$ ще «незміцнілих» сепсисних вогнищ в їх довкілля виділяється відносно невелика кількість збудників. Ситуація різко змінюється, коли настає час «дозрівання і спорожнення» в довкілля і кров декількох сепсисних вогнищ. Збудники та їх токсини несподівано (неначе без причини) «наповнюють» організм хворого, через що, здавалося б, відносно благополучний пацієнт без високої гарячки раптом стає украй тяжким з лякаючими стрибками гарячки і приголомшливими ознобами. Різкі підйоми і падіння температури з остудою і поганим самопочуттям - гектична гарячка (febris hectica) - дуже характерна для септикопіємічної стадії сепсису, яка $€$ клінічним проявом «спорожнення» В навколишні тканини і кров «дозрілих» сепсисних вогнищ.

Саме у цьому і полягає відмінність сепсису від усіх інших бактерійних захворювань [4-6]. Септикопіємічний період є завершальним 3 характерною різко вираженою і наростаючою злоякісністю.

Вторинні септокопіємічні запальні вогнища викликають органні ураження - сепсисну пневмонію, сепсисний пієлонефрит, сепсисний менінгіт та ін., а пов'язана 3 ними тяжка інтоксикація призводить до поліорганної недостатності, яка за відсутності спеціального лікування може стати причиною летального висліду.

Септикопіємічна інтоксикація може призвести до інфекційно-токсичного (сепсисного) шоку, який теж може закінчитися смертю. Лікування хворих у септикопіємічній стадії надзвичайно складне і вимагає спеціальної професійної підготовки і практичного досвіду.

Уявлення про септицемію і септикопіємію як стадій, що відображають динаміку сепсису, склалися в результаті клінічних спостережень декількох поколінь лікарів упродовж XIX-XX століть. Септицемія і септикопіємія характерні клінічні особливості, властиві саме сепсису і тільки йому.

Сепсисна імуносупресія транзиторна. Вона ліквідується в процесі етіотропного та імуновідновного лікування з пригніченням і/або ліквідацією збудника/збудників у сепсисному вогнищі/вогнищах. Тяжкість і тривалість процесу визначаються інтенсивністю проліферації збудника/збудників у сепсисному вогнищі/вогнищах.

Таким чином сепсис - інфекційне захворювання бактерійної та/або грибкової етіології із самопідтримуваним механізмом розвитку й особливою тяжкістю. Тяжкість зумовлена генералізованим характером інфрекційного процесу й толерантністю збудників до імунітету хворих і проявляється ациклічністю хвороби, тобто злоякісністю. Причина ациклічності - пригнічення захисних і відновних функцій імунітету хворих антигенами і суперантигенами збудників сепсису. Ациклічність означає неухильне наростання тяжкості та незмінний перехід початкової септицемічної стадії хвороби в завершальну септикопіємічну, через що одужання при сепсисі без спеціального лікування недосяжне. Етіотропна терапія таких хворих полягає у пригніченні і/або ліквідації збудників сепсису як першопричини захворювання, а відновлення порушених 


\section{ОГЛЯДИ ТА ЛЕКЦІї}

фрункцій імунітету є основою абсолютно необхідного патогенетичного лікування.

Клінічно сепсис - неоднопланове захворювання. Слід розрізняти найгостріший, гострий і хронічний сепсис.

Найгостріший сепсис триває від декількох годин до 1-2 діб. Звідси його друга назва - «блискавичний» сепсис. Його реєструють відносно нечасто - у близько 1 \% від усіх випадків сепсису [7].

Обов'язковим компонентом такого варіанту хвороби $€$ інсекційно-токсичний (сепсисний) шок - украй тяжкий вид шоку тому, що він розвивається саме при сепсисі - найбільш тяжкому і небезпечному з усіх інфекційних захворювань. Летальність при сепсисному шоці в межах $70 \%$ і більше.

Доцільно розрізняти:

а) ранній шок - артеріальний тиск (АТ) менше 90 мм рт. ст., що зберігається впродовж години, незважаючи на здійснюване лікування;

б) рефрактерний шок - АТ менше 90 мм рт. ст., що зберігається більше години, незважаючи на лікування.

Діагностика найгострішого сепсису, враховуючи гостроту процесу, можлива тільки на клінічному рівні і в усіх без винятку випадках має бути екстреною.

Доцільно підкреслити найбільш характерні клінічні ознаки інфекційно-токсичного шоку:

- страждальний вираз обличчя;

- погіршення самопочуття з можливим збудженням або депресією і різкою слабкістю;

- тахікардія і тахіпное, що не відповідають температурі тіла, випереджаючи їі;

- блідість покривів, особливо шкіри обличчя;

- гіпергідроз з характерними великими краплями поту на обличчі та інших ділянках тіла за відсутності гарячки («холодний піт»);

- можливе зниження температури шкіри рук і стоп, хоча при грампозитивному шоці покриви можуть залишатися сухими і теплими.

АТ при інфекційно-токсичному шоці становить 90/50 або 80/40 мм рт. ст. (чи на 40 мм рт. ст. нижче звичного для хворого максимального рівня), а на пізній стадії можливі 50/0 мм рт. ст. Слід уточнити, що 0 (нуль) у цих випадках означає, що нижній рівень АТ не визначається загальноприйнятим способом, але не вказує на повну відсутність нижнього рівня АТ.

Виявлення більшості з перерахованих ознак дозволяє достовірно розпізнати інфекційно-токсичний шок і визначити його ступінь.

Услід за тим потрібне клінічне уточнення можливої групової етіологічної приналежності розпізнаного найгострішого сепсису, що має прикладне значення для його етіотропної терапії.
Грампозитивний найгостріший сепсис пов'язаний переважно з альсратоксином S. aureus, що має дисциркуляторну і кардіодепресивну дію [4].

Симптоматика:

1) раптовий (найгостріший) підйом гарячки;

2) швидкий (в межах доби, a, можливо, і в перші години) розвиток гострої серцево-судинної, переважно судинної недостатності;

3) страх смерті.

Представлені ознаки можуть бути використані при їх виявленні (за наявності належного клінічного досвіду) як аргумент на користь застосування екстреної антистафрілококової терапії.

Можливі додаткові симптоми грампозитивного стафрілококового сепсису у вигляді великих підшкірних крововиливів - сугіляцій, підшкірних геморагій, вторинних гнійничкових висипань.

Великі підшкірні геморагії (сугіляції) при найгострішому стафілококовому сепсисі повинні розцінюватися як прогностично украй несприятлива ознака.

Грамнегативний найгостріший сепсис пов'язаний безпосередньо з ендотоксином грамнегативних бактерій - ліпополісахаридом бактерійної стінки, що викликає явища периферичної судинної недостатності без ознак недостатності серцевої [4].

Характерний найгостріший початок з різким підйомом гарячки, а потім падінням АТ і розвитком симптоматики шоку. На шкірі послідовно змінюються мармуровість, застійні колаптоїдні плями, які на кінцевій стадії хвороби можуть набирати вигляду великих гіпостатичних («трупних») плям, а також внутрішньошкірні та підшкірні крововиливи. Добре помітна схожість симптомів грамнегативного і грампозитивного сепсису на цій стадії недуги пояснюється розвитком шоку 3 переважанням у клінічній картині симптоматики саме шоку.

Класичним прикладом найгострішого грамнегативного сепсису є сепсис менінгококової етіології.

Менінгококова інфрекція може перебігати з характерним геморагічним висипом, який є ознакою її генералізації - менінгококцемії. Проте ознакою розвитку менінгококового сепсису сама менінгококцемія ще не $\epsilon$, адже вона може перебігати доброякісно і тоді, крім помірної гарячки і геморагічного висипу при задовільному або середньотяжкому стані, інших проявів хвороби не буде. Прогноз такого випадку сприятливий, особливо при призначенні антибіотика з групи бета-лактамних. Але ситуація може різко змінитися, якщо при появі менінгококцемії розвиваються симптоми інфекційно-токсичного шоку. Тоді і фрормується найгостріший менінгококовий сепсис як ускладнення генералізованої стадії менінгококової інфекції. 
Основна і найчастіша клінічна фрорма сепсису гострий сепсис. Подібно до найгострішого, він також може бути спричинений грампозитивними та грамнегативними збудниками. Грампозитивний гострий сепсис перебігає в цілому клінічно більш різноманітніше й відносно сприятливіше, ніж грамнегативний і реєструється приблизно в 3 рази частіше, ніж грамнегативний [4]. Можливий етіологічно змішаний варіант гострого сепсису (mixtsepsis), коли у хворого виявляються два і більше збудників, які можуть належати до різних класів грампозитивних і грамнегативнх бактерій, що цілком відповідає поліетіологічній природі сепсису.

Найбільш примітним клінічним проявом гострого cепсису, незалежно від його грампозитивної або грамнегативної етіології, $є$ гарячка. Хоча гектична гарячка належить до класичних проявів сепсису, її можна спостерігати не більше ніж в 1/3 хворих переважно в другому, завершальному септикопіємічному періоді хвороби. Але вона може проявлятися і з першого дня недуги, якщо розвивається первинна септицемія або септикопіємія. Практично можливі усі інші (крім febris hectica) варіанти температурних кривих і, навіть, повна відсутність гарячки (афебрильний сепсис).

Шкірні прояви при гострому сепсисі спостерігаються у вигляді:

- гнійних, переважно гнійничкових висипань, особливо на шкірі обличчя;

- геморагічних некрозів;

- дрібноміхурцевого (міліарного) висипу - Cristalina miliaria.

Гнійні/гнійничкові ураження шкіри (фрурункули, панариції, пароніхії, гнійничкові вогнища на верхній губі і підборідді при «синус-тромбоз сепсисі») $€$ переважно первинними гнійно-запальними процесами, що вказують на джерело і характер сепсисної (кокової) інсекції. Можливі і вторинні гнійно-запальні шкірні прояви на тлі розвинутого сепсису як результат дисемінації гнійної інорекції з первинного сепсисного вогнища або вторинних сепсисних вогнищ.

Геморагічні некрози шкіри є одним з можливих проявів сепсисної гіперкоагуляції безпосередньо в судинах шкіри. Вони можуть локалізуватися на дистальних відділах кінцівок, на пальцях, міжпальцевих складках, на тильних і долонних поверхнях кистей і стоп. Вказані некрози спостерігаються у вигляді утворень 3-7 мм в діаметрі, для них не характерна множинність і вони не обов'язково супроводжуються вираженою болючістю, тому частіше є видимими, ніж виявляються.

Міліарний висип - дуже характерний клінічний елемент гострого сепсису у вигляді дрібного (близько 1 мм в діаметрі) везикульозного висипу, розташованого в місцях 3 тонкою шкірою (нижня частина грудей, верхня частина живота, пахвові ділянки). Колір вмісту везикул злегка жовтуватий або прозорий, тому на загальному фоні вони не виділяються, через що є видимими ще частіше, ніж геморагічні некрози на дистальних частинах кінцівок.

Ураження внутрішніх органів $€$ запальними процесами, які спричинені бактеріями або грибами, - збудниками гострого сепсису. Вони можуть бути первинними, наприклад, пневмонія, міокардит, пієлонефрит, генітальні запальні процеси, гнійний холецистит, менінгіт, остеомієліт та ін., з яких фрормується первинне запальне сепсисне вогнище. Але значно частіше запальні процеси внутрішніх органів при гострому сепсисі розвиваються в завершальній септикопіємічній стадії гострого сепсису, оскільки є, по суті, метастатичними запальними вогнищами.

Важливо, що помірне збільшення розмірів печінки (при ультразвуковому дослідженні), але без клінічних ознак гострого гепатиту постійно буває при гострому сепсисі. У Грузинському протисепсисному центрі випадки гострого сепсисного гепатиту як ускладнення гострого сепсису спостерігалися рідко - близько 0,5 \% [7]. Ця деталь різко контрастує 3 твердженнями авторів і прибічників синдромальної системно-запальної теорії сепсису про те, що відбувається регулярна «транслокація» бактерій і ендотоксинів з кишечнику хворих на сепсис: «пасаж бактерій через епітелій слизової оболонки кишки у портальну систему і системний кровоплин з посиленням ендотоксинемії, ушкодженням печінки і пригніченням імунітету» $[12,13]$. Оскільки венозна кров відтікає від кишечнику безпосередньо через портальну систему, тобто фрактично через печінку, то при регулярній «транслокації» кишкових бактерій через печінку, гострий гепатит з жовтяницею спостерігався б при сепсисі не рідше, ніж сепсисна пневмонія, чого ніяк не спостерігається. Незважаючи на ефректний термін «транслокація», переміщення кишкових бактерій в печінку при сепсисі, безумовно, не правило, а рідкісний виняток.

Особливою групою інфекційних захворювань, що займає проміжне положення між сепсисом і хронічними інфекціями, є «хроніосепсис». Незважаючи на його назву, це не хронічний сепсис, адже його клінічна картина і перебіг не відповідають ні клінічній симптоматиці, ні клінічній динаміці сепсису. «Хроніосепсис» - це хронічна, переважно тяжка, інфекція з переважанням автоімунних, алергічних, колагенозоподібних та інших процесів. Назва «хроніосепсис» запропонований профр. В.Г. Бочоришвілі з обмовками про те, що при усій його можливій неочевидності, більш відповідної назви, ніж «хроніосепсис», поки не знайдено [7]. 


\section{ОГЛЯДИ ТА ЛЕКЦІї}

Як «хроніосепсис» фрігурував «інфрекційний або септичний ендокардит - запальне ураження клапанних структур і пристінкового ендокарда, обумовлене прямим проникненням збудників, що перебігає найчастіше на кшталт сепсису, гостро або підгостро, з циркуляцією збудників у крові, емболіями, імунопатологічними змінами та ускладненнями» [14].

Згідно з Міжнародною статистичною класифікацією хвороб і проблем, пов'язаних зі здоров'ям (МКX-10), «сепсис» позначений шифррами: A40, A41, A41.0 і далі від A41.1 до А41.9.

Усі шифри в МКХ-10 визначені як «Септицемія» уточненої і неуточненої етіології. Етіологія сепсису позначена тільки як бактерійна. Сепсис грибкової етіології не згадується.

Чому найменування «Сепсис» замінено на «Септицемія», в тексті не пояснюється. На жаль, поняття про сепсис як «септицемію» бактерійної або неуточненої етіології» відповідає застарілим уявленням про сепсис на рівні першої половини XX століття. Сподіваємося, це упущення буде враховане в новій Міжнародній статистичній класифрікації хвороб 11-го перегляду.

Лікування хворих на сепсис повинно бути своєчасним, комплексним та енергійним. У комплексі лікувальних заходів слід використовувати (крім хірургічної санації гнійних вогнищ) наступні компоненти:

1) пригнічення збудників та їх токсинів;

2) імунну реставрацію;

3) антикоагулянтні препарати;

4) пригнічення протеолітичних орерментів;

5) пасивну імунотерапію;

6) екстракорпоральну детоксикацію.

Проводять санацію первинного септичного вогнища (розтин і дренування абсцесу, видалення хворих зубів). За необхідності здійснюють хірургічне лікування і вторинних гнійних вогнищ. Після встановлення виду збудника потрібно якомога раніше почати етіотропне лікування. Важливо визначити чутливість збудника до антибіотиків.

Золотим стандартом лікування хворих на сепсис $\epsilon$ використання антибіотиків у найвищих фрармакопейних дозах, а бета-лактамних антибіотиків (пеніциліни, цесралоспорини, монобактами, карбапенеми) - у мегадозах, тобто дозах, що перевищують найвищі фрармакопейні в 5 (п'ять) або 10 (десять) разів. Протисепсисна антибіотикотерапія повинна тривати до нормалізації температури тіла і додатково ще в межах 5 діб. Повна відміна антибіотиків тільки після ліквідації усіх сепсисних запальних вогнищ. Оскільки зазначена етіотропна терапія сепсису не гарантує успіху одразу, то в усіх випадках, крім першого ряду антибіотиків, має бути передбачений і другий ряд, а також антибіотик/антибіотики резерву.
В усіх випадках імунної недостатності спостерігається дефіцит Т-клітинної ланки імунітету і недолік ендогенної продукції інтерлейкіну-2 (ІЛ-2), тому для лікування вторинної імунної недостатності має бути фрункціональний аналог ІЛ-2 - ронколейкін (в Україні не випускається) чи аналогічні засоби [15].

3 огляду на те, що при сепсисі завжди розвивається тромбогеморагічний синдром, хворим призначають гепарин. Чим тяжча інтоксикація, тим більше слід вводити гепарину (в межах від 20 до 80 тис. ОД/добу). При дуже тяжкому перебігу краща рівномірна (безперервна) гепаринізація, при якій гепарин вводять кожну годину крапельно з розчином глюкози. Гепаринізацію проводять під контролем клінічних проявів і тромбоеластограми, а також інших показників системи згортання крові. Різко виражений геморагічний синдром $€$ протипоказанням до застосування препарату. Призначаються також препарати, що пригнічують протеоліз (трасилол, контрикал) по 20 000-40 000 ОД/добу.

При лейкопенії застосовують засоби, що стимулюють лейкопоез: пентоксил, нуклекс, лейкоген тощо. Використовують і специфічні препарати, що містять протистафрілококові антитіла - протистафілококовий імуноглобулін і плазму. Людський протистафілококовий імуноглобулін вводять в дозі 20-30 МО/кг через день. Курс лікування - 3-5 ін'єкцій. Більш швидкий ефрект дає внутрішньовенне введення протистафрілококової плазми в дозі 4-6 мл/кг. Замість протистафрілококового імуноглобуліну можна використовувати нормальний плацентарний імуноглобулін, який також містить протистафрілококові антитіла. Гетерогенний протистафрілококовий імуноглобулін може містити велику концентрацію антитіл, однак застосування його при сепсисі небажане через можливість алергічних реакцій на чужорідний білок. Для лікування сепсису, обумовленого грамнегативними мікроорганізмами, в останні роки застосовують препарат, що містить моноклональні антитіла проти ендотоксину грамнегативних бактерій. При розвитку септичного шоку проводять відповідний комплекс заходів.

Цілком очевидно, що неправильне розуміння природи сепсису може негативно позначитися на результатах лікування септичного хворого. Ми неодноразово стикалися 3 подібними випадками. Наводимо витяг 3 медичної карти стаціонарної хворої, що ілюструє останній такий випадок.

Хвора С.М., вік 24 роки, проживає в Тернополі. Була ушпиталена в обласну психоневрологічну лікарню 11.07.2018 р. з діагнозом «Менінгіт?». Захворіла 25.06.18 р., коли вперше звернула увагу на збільшений помірно болючий задньошийний лімфратичний вузол зліва. 3 29.06.18 р. почало турбувати підвищення температури тіла до $37,2-37,6{ }^{\circ} \mathrm{C}$, яка зберігалася про- 
тягом наступного тижня. 2.07.18 р. уперше була оглянута сімейним лікарем, який діагностував «ГРВІ» та призначив аугментин (?) у традиційній добовій дозі і лімфоміозот.

Попри зазначене лікування, через 3 доби температура тіла періодично стала підвищуватися до 39$40{ }^{\circ} \mathrm{C}$. Такі епізоди гіперпірексії відзначалися декілька разів на добу й супроводжувалися остудою та інтенсивним потінням. Водночас хвору турбував сильний біль голови. Повторно була оглянута лікарем, який на підставі зазначених даних, а також сумнівної ригідності потиличних м'язів запідозрив менінгіт і скерував пацієнтку до відповідного спеціалізованого лікувального закладу. Значне збільшення задньошийного лімфратичного вузла зліва ескулап проігнорував.

Стан пацієнтки при ушпиталенні тяжкий, обумовлений інтоксикацією: відзначаються млявість, сонливість, обмеження рухів у шиї через болючість, гарячка фебрильна до 38,0-39,5 ${ }^{\circ} \mathrm{C}$. Візуально на шиї зліва помітний збільшений задньошийний лімфатичний вузол до 3,0 см у діаметрі; при пальпації він щільний, болючий. Праворуч задньошийні лімфратичні вузли дрібні, розміром до 0,5 см в діаметрі, безболісні. Інші групи лімфатичних вузлів не збільшені. Слизова оболонка ротоглотки помірно гіперемована, мигдалики не збільшені, нальотів немає.

з боку легень і серця патологічних змін не виявлено, хоча встановлено фрізіологічну тахікардію, що відповідала температурі тіла.

Живіт м'який, доступний глибокій пальпації, при якій виявлено, що печінка виступає з-під краю реберної дуги по середньоключичній лінії на 2,0 см, щільно-еластичної консистенції, не болюча. Селезінка не пальпується. Випорожнення оформлені, сечовипускання не порушене.

Загальний аналіз крові: гемоглобін 128 г/л, еритроцити 3,94 Т/л, лейкоцити 12,0 Г/л, ШОЕ 22 мм/год, паличко-ядерні нейтрофріли $23 \%$, сегменто-ядерні нейтрофріли 59 \%, лімфоцити $13 \%$, моноцити 3 \%, еозинофріли $2 \%$.

Біохімічне дослідження: загальний білірубін 22 мкмоль/л, АЛТ 0,44 ммоль/лхгод, АСТ 0,63 ммоль/ лхгод, тимолова проба 3,5 од.; сечовина 5,2 ммоль/л, креатинін 0,09 ммоль/л.

Загальний аналіз сечі без особливостей.

Протягом наступних 3 днів стаціонарного лікування хворій була здійснена спинно-мозкова пункція, МРТ головного мозку, консультована хірургом і гематологом. При цьому жодних об'єктивних даних за органічне ураження головного мозку і мозкових оболонок не було. УзД і пункція задньошийного лімфатичного вузла зліва не вказували на наявність у ньому гною.
Дослідження крові на показники системних ревматологічних захворювань негативні. Методом ІФА у крові виявлено IgG до герпесвірусів (HSV-1/2, EBV, CMV), токсоплазм і вірусу краснухи у помірно підвищених тuтрах за відсутності відповідних IgM. Рівень прокальцитоніну становив 11,5 нг/мл, що суттєво перевищувало допустиме значення (0,5-1,8 нг/мл), вказуючи на наявність тяжкої бактерійної інфекції.

Посів крові на стерильність - виділений S. epidermidis.

3 діагнозом «Задньошийний лімфраденіт зліва» 13.07.18 р. пацієнтка була переведена в хірургічне відділення університетської клінічної лікарні.

УзД лімфратичних вузлів шиї: на задньобоковій поверхні шиї зліва виявлені спаяні лімфатичні вузли розміром 35×15 мм без вогнищ розрідження. При ультразвуковому дослідженні органів черевної порожнини від 14.07.18 p. у верхньозадньому латеральному сегменті печінки визначалося гіпоехогенне вогнище 30 мм в діаметрі, в проекції - п'ять порожнин, розміром до 5 мм у діаметрі. У парамедіанному секторі лівої частки печінки відзначалося чотири гіпоехогенні вогнища розміром від 5 до 12 мм у діаметрі. У паренхімі селезінки виявлені гіпоехогенні вогнища, розміром максимальний до 5 мм у діаметрі.

Результати комп'ютерної томограсфії шиї, органів грудної порожнини, черевної порожнини і заочеревного простору: по задній бічній поверхні шиї зліва визначалося утворення з чітким нерівним контуром, розміром 32х18 мм, що мало нерівномірно потовщену капсулу (до 3-5 мм), яка інтенсивно накопичувала контрастну речовину. По бічних поверхнях шиї з обох боків помітні лімфратичні вузли розміром до 10 мм у діаметрі.

У легенях вогнищевих та інфрільтративних тіней не було. У середостінні додаткових утворень і збільшення лімфратичних вузлів не виявлено.

Структура печінки неоднорідна за рахунок множинних гіподенсивних округлих утворень без чітких контурів, що накопичували контрастну речовину по периферії. Внутрішньо- і позапечінкові протоки не розширені. У селезінці після внутрішньовенного посилення в портальну фазу контрастування візуалізувалися множинні гіподенсивні ділянки розміром до 5 мм у діаметрі.

Жовчний міхур: вміст однорідний, стінка не потовщена.

Підилункова залоза: контури чіткі. Щільність звичайна, структура однорідна, розміри звичайні. Парапанкреатична клітковина не змінена.

Нирки розташовані типово, структура паренхіми однорідна, щільність звичайна. ЧМС не розширені, рентґено-контрастних конкрементів не виявлено. Паранефральна клітковина не змінена. 


\section{ОГЛЯДИ ТА ЛЕКЦІї}

Висновок: великий одиничний абсцес по задньобоковій поверхні шиї зліва, дрібні множинні абсцеси в печінці та селезінці.

Хвора була консультована фртизіатром, онкологом, ревматологом, гінекологом і повторно гематологом - туберкульоз, дифузні захворювання сполучної тканини, запальні захворювання матки і придатків, а також лімфопроліферативні захворювання виключені.

17.07.18 р. здійснене оперативне видалення лімфатичного вузла (після асептичної обробки операційного поля зроблено лінійний розріз шкіри, лімфратичний вузол видалений тупим і гострим шляхами. Після його розкриття отримано до 10 мл рідкого гною).

Висновок патолого-гістологічного дослідження: в представленому препараті виявлена картина гнійнонекротичного лімфраденіту.

Бактеріологічне дослідження гною також засвідчило picm S. epidermidis.

Незважаючи на успішно проведену операцію і на постійно здійснювану протибактерійну терапію (сульбактомакс, ципринол, кларитроміцин, метронідазол у середньотерапевтичних дозах), загальний стан хворої продовжував залишатися тяжким, утримувалася фребрильна гарячка, у зв'язку з чим пацієнтка була переведена у відділення реанімації та інтенсивної терапії.

20.07.18 р. був проведений консиліум у складі хірургів, анестезіологів-реаніматологів, онколога, гематолога, інфрекціоніста, імунолога, який неодностайно прийшов до такого висновку: «Генералізована інфекція неуточненої етіології. Ускладнення - синдром системної запальної відповіді».

Щоправда, інфрекціоніст записав окрему думку: «Гострий сепсис, не виключено стрептококової етіології (S. epidermidis), стадія септикопіємії: задньошийний лімфраденіт зліва, множинні абсцеси печінки і селезінкU».

Лікування було скориговане: антибактерійна терапія: меронем 1,0 г в/в тричі на добу, гатифрлоксацин 0,8 г в/в 1 раз на добу, ванкоміцин 1,0 г двічі на добу в/в), фрлуконазол 0,4 г/добу; біовен; інфузійна дезінтоксикаційна та симптоматична терапія.

Протягом 1 тиж зазначеної терапії загальний стан хворої суттєво покращав, температура тіла нормалізувалася. Рівень прокальцитоніну знизився до 2 нг/ мл. УЗД печінки і селезінки засвідчило регрес абсцесів. Пробувши у стаціонарі сумарно 29 діб, пацієнтка у стані одужання була виписана додому. Хірург усе ж частково врахував позицію інфрекціоніста, виставивши остаточний діагноз: «Септицемія стрептококової етіології (S. epidermidis): задньошийний лімфраденіт зліва (оперативно видалений 17.07.18р.), множинні абсцеси печінки і селезінки».
Дуже подібний випадок у дитини був описаний І.В. Богадельніковим і співавт. (2014) [8].

Як видно з наведеного клінічного випадку, на підставі характерних клінічних ознак (інтоксикація, особливості гарячки, наявність гнійних вогнищ у лімфатичному вузлі та паренхімі печінки й селезінки, які, ймовірно, сфрормувалися внаслідок гематогенного розповсюдження збудника), лабораторних показників, що вказували на значні запальні зміни, бактеріологічного виділення S. epidermidis з крові, а пізніше - і з гнійного відокремлюваного, отриманого з видаленого шийного лімфовузла, можна було діагностувати сепсис.

Зрозуміло, що у хворої розвинулася друга стадія сепсису - септикопіємія, адже були сорормовані вторинні гнійні вогнища у печінці та селезінці. Однак згідно 3 нині чинною Міжнародною класифрікацією хвороб 10-го перегляду, діагноз «Сепсис» визначений лише у фрормі «Септицемія» уточненої або неуточненої бактерійної етіології. Тому хірург вимушений був виставити кінцевий діагноз «Септицемія», хоча він і не відповідав клінічним проявам хвороби на той період часу.

Протягом перших днів хвороби, коли на фоні періодично виникаючої гектичної гарячки, що супроводжувалася симптомами інтоксикації, запальними змінами показників периферичної крові, хоча УЗД та пункція лімсратичного задньошийного вузла, збільшеного у той час до 3 см в діаметрі, не підтвердили наявність у ньому гною. Але із законів інфектології відомо, що коли в початковому періоді хвороби є первинно ссрормоване сепсисне вогнище (в конкретному випадку лімсровузол), то сепсисна бактеріємія настає періодично. Клінічно такі періоди супроводжувалися наростанням гарячки та інших проявів інтоксикації, що чергувалися з періодами зниження температури тіла і тимчасовим покращанням загального стану хворої. Фактично це було початковим періодом сепсису - стадією септицемії. Як відомо, ця стадія досить короткочасна (в середньому 7-10 діб), оскільки кров не є середовищем, сприятливим для тривалого перебування мікроорганізмів. Тому збудник може вижити тільки тоді, коли зафіксується в тканинах [9], тобто сорормуються вторинні гнійні вогнища. Це відповідає стадії септикопіємії - періоду, що свідчить не лише про певну тривалість процесу, але й вказує на терапевтично задавнену септицемію. На стадії септикопіємії процес ніколи самостійно не зупиняється і без серйозного лікування неодмінно закінчується летально. Це відбувається тому, що сепсис - єдина фрорма інфрекції, що має самопідтримуваний механізм розвитку $[4,8]$, тобто $є$ «ациклічним іноекційним процесом». У такому разі періоди загострень поєднуються з періодом ремісії, але ніколи не закінчуються ерадикацією збудника [1618]. 
Для успішного лікування на етапі септицемії, крім потужної антибактерійної та іншої терапії, абсолютно необхідна ліквідація первинного вогнища. Такий метод лікування був визначений ще з часів Гіппократа в медичному законі: «Ubi pus - ibi incisio» («Де гній - там розріз»). На жаль, це було зроблено надто пізно - тільки після того, коли періодична фебрильна гарячка змінилася постійною гіпертермією, розміри периферичного задньошийного лімсровузола зліва зросли ще значніше та було підтверджене його нагноєння, а також сорормувалися численні вторинні абсцеси у печінці й селезінці, тобто у стадії септикопіємії.

На щастя, хвора благополучно одужала - тільки після усунення «материнського» гнійного вогнища і призначення обов'язкової при сепсисі потужної і тривалої антибіотикотерапії. Цей фракт є ще одним непрямим підтвердженням неспроможності синдромальної гіпотези сепсису.

Таким чином, визначаючи наріжним каменем при сепсисі «системність» запальної відповіді у вигляді цитокінових порушень, автори відповідної концепції змушені визнавати етіологічними фракторами практично усі без винятку збудники інфекційних захворювань (від вірусів до найпростіших), які закономірно перебігають 3 підвищенням активності цитокінів у сироватці крові. Не применшуючи значення цих важливих компонентів запалення, ще раз звернемо увагу на постулат про те, що не тільки віруси та найпростіші ніколи не спричиняють сепсис [4-8, 16], але й усі «небактеріємічні збудники» (клостридії ботулізму та правця, бордетелли кашлюка, дистерійні палички, холерні вібріони та ін.) за визначенням не бувають етіологічними фракторами цього захворювання, хоча й неодмінно зумовлюють тяжкі системні реакції, що супроводжуються збільшенням рівня прозапальних цитокінів. Оманливість згаданої теорії полягає ще й у трактуванні запалення як системного, тобто генералізованого явища. Біологічна мета будь-якого інфрекційного запалення - це локалізація, тобто обмеження певним місцем, не допускання поширення збудника. Тому якщо йдеться про системний процес, то це аж ніяк не запалення, а щось зовсім інше. Хоча, варто визнати, що системне запалення може стосуватися передусім процесу асептичного чи автоімунного.
Тим часом основні положення синдромної концепції сепсису зазнавали разючих змін. Так, група експертів в галузі інтенсивної терапії, інфрекційних хвороб, хірургії та пульмонології в 2014 р. запропонувала ввести в клінічну практику «нові» його визначення. Ведучи хронологію відліку критеріїв сепсису від «узгоджувальної» комісії 1991 р. і беручи до уваги результати робочої групи міжнародних медичних товариств 2001 р., був розроблений документ, який отримав назву «Третій міжнародний консенсус з визначення сепсису і септичного шоку (сепсис-3)». У зв'язку з цим, у 2016 р. групою дослідників Sepsis-3 замість SIRS для визначення швидкої оцінки сепсису і тяжкості органо-септичних порушень було запропоновано користуватися шкалою SOFA (Sepsis organ failure assessment) (quick SOFA або qSOFA - експрес SOFA) як спрощеною версією показника SOFA та первинного способу виявлення пацієнтів з високим ризиком несприятливого висліду хвороби. При цьому підвищення бальності за qSOFA мало б загострити увагу клініциста на пошук інфекції, поглибити обстеження хворого, провести більш ретельний моніторинг. Критерії SIRS були визнані нераціональними, що мають багато обмежень [19, 20]. На 45-у конгресі SCCM (Society Critical Care Medicine) у цьому ж році було заявлено, що поточне використання 2 або 3 критеріїв SIRS для виявлення сепсису $є$ марним. A qSOFA мало б значно спростити оцінку SOFA, що містить 3 критерії без очікування лабораторних показників з включенням порушення свідомості. Так, індекс quick враховує парціальний тиск кисню, частку вдихуваного кисню, число тромбоцитів, бали за шкалою коми Глазго, рівень білірубіну, ступінь гіпотензії та рівень креатиніну.

Однак і ця концепція зазнала нищівної критики. Адже вже у квітні 2018 р. були опубліковані результати 38 багатоцентрових досліджень, що включали понад 385 тис. пацієнтів, які переконливо доводять погану чутливість і помірну специфрічність критеріїв qSOFA [21].

Тож синдромну концепцію сепсису інакше як консруз охарактеризувати складно. Проблема полягає ще й у тому, що пропозиція відмовитися від симптомів SIRS зумовила розчарування медичної спільноти, оскільки базовими для більшості національних і міжнародних рекомендацій стало визначення ACCP/SCCM 1991 р. Тому погляди науковців на сепсис сьогодні різні як ніколи. 


\section{ОГЛЯДИ ТА ЛЕКЦІї}

\section{Література}

1. Definitions for sepsis and organ failure and guidelines for the use of innovative therapies in sepsis. The ACCP/SCCM Consensus Conference Committee. American College of Chest Physicians/Society of Critical Care Medicine / R.C. Bone, R.A. Balk, F.B. Cerra [et al.] // Chest. - 1992. - Vol. 101 (6). - P. 1644-1655.

2. Глумчер Ф.С. Септический шок: новые концепции патогенеза и лечения / Ф.С. Глумчер // Мистецтво лікування. - 2004. - № 8. - C. 4-8.

3. Малый В.П. Сепсис в практике клинициста: монография / В.П. Малый. - Х.: Прапор, 2008. - 584 с.

4. Ребенок Ж.А. Сепсис: современные проблемы / Ж.А. Ребенок. - Минск: Четыре четверти, 2007. - 280 с.

5. Ребенок Ж.О. Сепсис: розпізнавання і лікування / Ж.О. Ребенок // Інфекційні хвороби. - 2008. - № 3. - С. 53-59.

6. Ребенок Ж.О. Сучасна реаніматологія: можливості удосконалення / Ж.О. Ребенок // Інфекційні хвороби. - 2010. - № 2. - С. 85-88.

7. Сепсисология с основами инфекционной патологии / под ред. В.Г. Бочоришвили. - Тбилиси: Мецниереба, 1998. - 807 с.

8. Сепсис - инорекционная болезнь или неудачное сочетание лабораторных показателей. Два взгляда на проблему / [И.В. Богадельников, Е.А. Крюгер, А.В. Бобрышева и др.] // Современная педиатрия. - 2014. - № 6(62). - C. 31-35. doi 10.15574/SP.2014.62.31

9. Surviving sepsis campaign: a project to change sepsis trajectory / [E. Silva, N. Akamine, R. Salomao et al.] // Endocr. Metab. Immune Disord. Drug Targets. - 2006. - Vol. 6(2). - P. 217-222.

10. Коен Д. Современные подходы к лечению сепсиса: есть ли новые надежды?/ Д. Коен // Клиническая микробиология и антимикробная терапия, 2002. - Т. 4, № 2. - С. 300-312.

11. Мишнев О.Д. Сепсис в начале XXI века: Классифиикация, клинико-диагностические концепции и лечение: Практическое руководство / О.Д. Мишнев, А.И. Щеголеева, О.А. Трусов. - М.: Изд.-во НЦССХ им. Бакулева РАМН, 2004. - С. 111-126.

\section{References}

1. Bone, R.C., Balk, R.A., Cerra, F.B., Dellinger, R.P., Fein, A.M., Knaus, W.A., Schein, R.M., \& Sibbald, W.J. (1992). Definitions for sepsis and organ failure and guidelines for the use of innovative therapies in sepsis. The ACCP/SCCM Consensus Conference Committee. American College of Chest Physicians/Society of Critical Care Medicine. Chest, 101(6): 1644-55.

2. Glumcher, F.S. (2004). Septicheskiy shok: novyye kontseptsii patogeneza i lecheniya [Septic shock: new concepts of pathogenesis and treatment]. Mystetstvo likuvannia - Art of Treatment, 8, 4-8 [in Russian].

3. Malyy, V.P. (2008). Sepsis v praktike klinitsista [Sepsis in the practice of a clinician]. Kharkov: Prapor [in Russian].

4. Rebenok, Zh.A. (2007). Sepsis: sovremennyye problemy [Sepsis: modern problems]. Minsk: Chetyre chetverti [in Russian].

5. Rebenok, Zh.O. (2008). Sepsys: rozpiznavannia i likuvannia [Sepsis: Recognition and treatment]. Infektsiini khvoroby - Infectious Diseases, 3, 53-59 [in Ukrainian].

6. Rebenok, Zh.O. (2010). Suchasna reanimatolohiia: mozhlyvosti udoskonalennia [Modern resuscitation: opportunities for improvement]. Infektsiini khvoroby - Infectious Diseases, 2, 85-88 [in Ukrainian].

7. Bochorishvili, V.G. (1998). Sepsisologiya s osnovami infektsionnoy patologii [Sepsisology with the basics of infectious pathology]. Tbilisi: Metsniyereba [in Russian].
12. $9^{\text {th }}$ European Congress of Anastesiology Ierusalim (Israel, Oktober 2-7). - 1997. - P. 125-139.

13. Van Leeuwen P.A. Клиническое значение транслокации / P.A. Van Leeuwen, M.A. Boermeester, A.P. Houdijk // Сепсис: сб. ст. и реорератов. - Киев: Нора-Принт, 1997. - С. 17.

14. Тюрин В.П. Инфекционные эндокардиты / В.П. Тюрин. - М.: Гэотар-Мед, 2002. - 222 с.

15. Попович А.М. Интерлейкин-2: опыт клинического применения / А.М. Попович, В.Н. Егорова. - СПб: «Новости правопорядка», 2006. -40 c.

16. Супотницкий М.В. Микроорганизмы, токсины и эпидемии / М. В. Супотницкий. - М., 2005. - 376 с.

17. Супотницкий М.В. Эволюционная патология. К вопросу о месте ВИЧ-инфекции и ВИЧ/СПИД-пандемии среди других инсекционных, эпидемических и пандемических процессов : моно грасрия / М.В. Супотницкий. - М. : Вузовская книга, 2009. - 400 с.

18. «Угадай мелодию» - многокомпонентные циклические и нециклические инсекционные процессы в практике педиатра / Богадельников И.В., Крюгер Е.А., Бобрышева А.В. [и др.] // Здоровье ребенка. - 2013. - № 4 (47). - С. 83-93.

19. Prognostic accuracy of the quick sequential organ failure assessment for mortality in patients with suspected infection: A systematic review and meta-analysis / S. M. Fernando, A. Tran, M. Taljaard [et al.] // Ann. Intern. Med. - 2018. - Vol. 168 (4). - P. 266275. doi: 10.7326/M17-2820.

20. Systemic inflammatory response syndrome criteria in defining severe sepsis / K.-M. Kaukonen, M. Bailey, D. Pilcher [et al.] // N. Engl. J. Med. - 2015. - Vol. 372. - P. 1629-1638. doi: 10.1056/ NEJMoa1415236

21. Rational Evidence Based Evaluation of Literature in Emergency Medicine. The SIRS \& qSOFA Confusion in Sepsis. - 16 April 2018 - E-resourse: http://rebelem.com/the-sirs-qsofa-confusion-in-sepsis/

8. Bogadelnikov, I.V., Kruger, E.A., Dyadyura, E.N., Mazinova, E.R., \& Bezdolnaya, T.N. (2014). Sepsis - infektsionnaya bolezn ili neudachnoye sochetaniye laboratornykh pokazateley. Dva vzgliada na problemu [Sepsis - the infectious disease or unsuccessful combination of laboratory parameters. Two views on the issue]. Sovremennaya pediatriya - Modern Pediatrics, 6 (62), 31-35. doi 10.15574/ SP.2014.62.31 [in Russian]

9. Silva, E., Akamine, N., Salomao, R., Townsend, S.R., Dellinger, R.P., Levy M. (2006). Surviving sepsis campaign: a project to change sepsis trajectory. Endocr. Metab. Immune Disord. Drug Targets, 6 (2), 217-222.

10. Koyen, D. (2002). Sovremennyye podkhody k lecheniyu sepsisa: yest li novyye nadezhdy? [Modern approaches to the treatment of sepsis: are there any new hopes?] Klinicheskaya mikrobiologiya $i$ antimikrobnaya terapiya - Clinical Microbiology and Antimicrobial Therapy, 4, 2, 300-312 [in Russian].

11. Mishnev, O.D., Shchegoleyeva, A.I., \& Trusov, O.A. (2004). Sepsis $v$ nachale $X X I$ veka: Klassifikatsiya, kliniko-diagnosticheskiye kontseptsii $i$ lecheniye [Sepsis at the beginning of the XXI century: Classification, clinical diagnostic concepts and treatment]. Moscow: Izd.-vo NTSSSKH im. Bakuleva RAMN [in Russian].

12. $9^{\text {th }}$ European Congress of Anastesiology Ierusalim (1997, Israel, Oktober 2-7). (pp. 125-139). 
13. Van Leeuwen, P.A., Boermeester, M.A., \& Houdijk, A.P. (1997). Klinicheskoye znacheniye translokatsii [The clinical significance of translocation]. In Sepsis: sb. st. i referatov [Sepsis: a collection of articles and abstracts]. Kyiv: Nora-Print [in Russian].

14. Tyurin, V.P. (2002). Infektsionnyye endokardity [Infective endocarditis]. Moscow: Geotar-Med [in Russian].

15. Popovich, A.M., \& Yegorova, V.N. (2006). Interleykin-2: opyt klinicheskogo primeneniya [Interleukin-2: clinical experience]. SaintPetersburg: "Novosti pravoporyadka" [in Russian].

16. Supotnitskiy, M.V. (2005). Mikroorganizmy, toksiny i epidemii [Microorganisms, toxins and epidemics]. Moscow [in Russian].

17. Supotnitskiy, M.V. (2009). Evolyutsionnaya patologiya. K voprosu o meste VICH-infektsii i VICH/SPID-pandemii sredi drugikh infektsionnykh, epidemicheskikh i pandemicheskikh protsessov [Evolutionary pathology. On the issue of the place of HIV-infection and HIVIAIDS-pandemic among other infectious, epidemic and pandemic processes]. Moscow: Vuzovskaya kniga [in Russian].

\section{SEPSIS - SYNDROME OR INFECTIOUS DISEASE? EVOLUTION OF DILEM}

\author{
V.S. Kopcha \\ I. Horbachevsky Ternopil State Medical University
}

SUMMARY. The aim of the study is to draw the attention of physicians to the discrepancy between the «new» notions about sepsis imposed on the medical community and definitely accepted not only by anesthetists, resuscitative surgeons and surgeons, but also by many infectionists.

By defining the cornerstone of sepsis as the «systemic» of the inflammatory response in the form of cytokine violations, the authors of the corresponding concept are forced to recognize the etiological factors almost all without exception, pathogens of infectious diseases (from viruses to the simplest), which naturally go with the increased activity of cytokines in serum. Without diminishing the importance of these important components of inflammation, one should pay attention to the postulate that not only viruses and protozoa never cause sepsis, but also all «non-bacterial pathogens» (clostridia of botulism and tetanus, borthetels of whooping cough, diphtheria sticks, cholera vibrios, etc.) by definition, there are no etiological factors of this disease, although they necessarily lead to severe systemic reactions accompanied by an increase in the level of proinflammatory cytokines.
18. Bogadelnikov, I.V., Kryuger, Ye.A., Bobrysheva, A.V., Mazinova, E.R., Dyadyura, Ye.N., \& Smirnov, G.I. (2013). «Ugaday melodiyu" - mnogokomponentnyye tsiklicheskiye i netsiklicheskiye infektsionnyye protsessy v praktike pediatra ["Guess the melody" multi-component cyclic and non-cyclic infectious processes in pediatric practice]. Zdorovye rebenka - Health of a Child, 4 (47), 83-93 [in Russian].

19. Fernando, S.M., Tran, A., Taljaard, M., Cheng, W., Rochwerg, B., Seely, A.J.E., \& Perry, J.J. (2018). Prognostic accuracy of the quick sequential organ failure assessment for mortality in patients with suspected infection: A systematic review and meta-analysis. Ann. Intern. Med., 168 (4), 266-275.

20. Kaukonen, K.-M., Bailey, M., Pilcher, D., Cooper, D.J., \& Bellomo, R. (2015). Systemic inflammatory response syndrome criteria in defining severe sepsis. N. Engl. J. Med., 372, 1629-1638.

21. Rational Evidence Based Evaluation of Literature in Emergency Medicine. (2018). The SIRS \& qSOFA Confusion in Sepsis. E-resourse: http://rebelem.com/the-sirs-qsofa-confusion-in-sepsis/
Therefore, sepsis is a generalized acyclic infectious disease of the bacterial and / or fungal etiology that develops in an immunodeficient organism with characteristic pathomorphological and pathologist changes in organs and tissues.

A detailed analysis of the clinical case of sepsis in a young woman is presented, which, due to adequate active surgical and powerful and long-term conservative therapy, has safely recovered.

Key words: sepsis; systemic inflammatory response syndrome; diagnosis; treatment.

\section{Відомості про автора:}

Копча Василь Степанович - д. мед. н., професор кафедри інфекційних хвороб з епідеміологією, шкірними і венеричними хворобами Тернопільського державного медичного університету ім. І.Я. Горбачевського; e-mail: kopcha@ukr.net

\section{Information about author:}

Kopcha V.S. - Doctor of Medicine, Professor of the Infectious Diseases and Epidemiology, Skin and Venereal Illnesses Department of I. Horbachevsky Ternopil State Medical University; e-mail: kopcha@ukr.net

Консрлікту інтересів немає.

Author has no conflict of interest to declare.

Отримано 26.09.2018 p. 